\title{
Effect of Planting Date and Inoculum Density on Severity of Fusarium Wilt of Lettuce in California
}

\author{
Kelley R. Paugh and Thomas R. Gordon ${ }^{\dagger}$ \\ Department of Plant Pathology, University of California, Davis, CA 95616
}

\begin{abstract}
Seven lettuce cultivars were transplanted into a field infested with Fusarium oxysporum $\mathrm{f}$. sp. lactucae (causal agent of Fusarium wilt of lettuce) in August and September of 2014, 2015, and 2016. For moderately susceptible cultivars, 1 - or 2-week differences in planting date had a significant effect on severity of Fusarium wilt. In growth chamber experiments, cultivars of moderate susceptibility were maintained in a growth chamber under cool conditions $\left(23 / 18^{\circ} \mathrm{C}\right)$, and a subset of plants was transferred to a warm chamber $\left(33 / 23^{\circ} \mathrm{C}\right)$ for 1 week, at weekly intervals after trans-

and August 2017, moderately susceptible cultivars were planted into field soil with an inoculum density gradient. Moderately susceptible cultivars were little affected by Fusarium wilt where inoculum densities of F. oxysporum f. sp. lactucae were $<125$ per gram of soil, even in warm planting windows. Adjusting planting dates to avoid high temperatures during a critical stage of growth and maintaining low inoculum density in soil can contribute to management of Fusarium wilt in moderately susceptible lettuce cultivars.
\end{abstract} planting. Plants exposed to high temperatures at 2 and 3 weeks after transplanting (WAT) had more severe symptoms of Fusarium wilt than those exposed at 4 WAT. In October 2015, April 2016, August 2016,
Keywords: fungi, vegetables, disease management, cultural and biological practices, soilborne disease
Fusarium oxysporum f. sp. lactucae was described as a pathogen of lettuce (Lactuca sativa) in 1955 in Japan and was determined to be pathogenic only to lettuce and no other tested vegetable crops (Matuo and Motohashi 1967). In 1990, the same pathogen was discovered in California as a cause of disease in crisphead (= iceberg) lettuce (Hubbard and Gerik 1993). Fusarium wilt of lettuce has since become more widespread and is now present in all major lettuce producing regions in California and Arizona (Matheron and Koike 2003). Establishment of the pathogen in these two states may have been facilitated by movement of infested soil on farming equipment (Gordon and Koike 2015; Matheron and Koike 2003), whereas movement between continents likely occurred on infested seed (Garibaldi et al. 2004a).

Symptoms of Fusarium wilt consist of stunting, chlorosis, and wilting, followed by death of leaves and collapse of plants. Host resistance is the most effective means of achieving control, but high levels of resistance have been identified only in some leaf and romaine types, with all crisphead cultivars being susceptible to some degree (Garibaldi et al. 2004b; Matheron et al. 2005; Scott et al. 2010b). Control of Fusarium wilt is further complicated by the long-term persistence of pathogen propagules in soil, whereby even in the absence of a susceptible host, the pathogen can survive by colonizing the roots of resistant cultivars and rotation crops (Scott et al. 2014). Crop rotation, with appropriate choice of crops (Scott et al. 2014), and solarization (Matheron and Porchas 2010) can reduce soil populations of $F$. oxysporum $\mathrm{f}$. sp. lactucae, but given the lack of cost-effective fumigation options, the pathogen is unlikely to be eradicated from soil. As the pathogen becomes more widespread in lettuce producing regions, growers will increasingly be in need of

${ }^{\dagger}$ Corresponding author: T. R. Gordon; trgordon@ucdavis.edu

Funding: The research on which this manuscript is based was supported by grants from the California Leafy Greens Board, awards from the StorkanHanes-McCaslin Research Foundation, and funding from USDA National Institute of Food and Agriculture through Hatch project CA-D-PPA-6699-H.

The author(s) declare no conflict of interest.

Accepted for publication 1 February 2019.

() 2019 The American Phytopathological Society practices that lower the risk of damage from Fusarium wilt in susceptible lettuce cultivars.

Development of Fusarium wilt of lettuce is strongly influenced by the temperature at and after planting (sowing) time, with more severe disease manifesting at higher temperatures. For lettuce cultivars of intermediate susceptibility, Scott et al. (2010a) reported that only mild symptoms of Fusarium wilt developed under cool conditions, with progressively more severe symptoms at higher temperatures. Similar results were obtained in Arizona, where a dramatically lower incidence of Fusarium wilt was observed for lettuce sown in cooler planting windows (Matheron et al. 2005). In California, differential development of Fusarium wilt in the Pajaro Valley and at the southern end of the Salinas Valley supports the importance of temperature in influencing disease severity. Mean daily temperatures in King City, where Fusarium wilt has become a significant problem, are much higher than in the Pajaro Valley, where the disease was observed in 2002 but failed to become established (Scott et al. 2012). Within a region, temperatures to which a crop is exposed will be influenced by planting date.

Severity of disease may also be influenced by the density of pathogen inoculum in soil. Presently, little is known about the relationship between inoculum density and the incidence and severity of Fusarium wilt of lettuce, but it is clear that there is a threshold below which a susceptible cultivar will not develop symptoms (Scott et al. 2012). A better understanding of how inoculum density influences development of disease could assist growers in reducing the risk of damage from Fusarium wilt.

The present study was undertaken to provide information concerning the effects of planting date and inoculum density on development of Fusarium wilt in lettuce. Accordingly, one objective was to monitor severity of disease in lettuce cultivars planted on three dates 1 week apart during late summer. The second objective was to test for an effect of temperature on development of Fusarium wilt in lettuce at different stages of growth. Lastly, development of Fusarium wilt was examined in plots with a range of inoculum levels in soil.

\section{Materials and Methods}

Planting dates 1 to 2 weeks apart. Lettuce seedlings. Based on prior field observations, seven lettuce cultivars were selected to represent a range of susceptibilities to Fusarium wilt: mild (Fossey), moderate (Diamondback, Sidewinder, and Steamboat), and high susceptibility (Bondi, Gabilan, and Salute). Lettuce cultivars were of 
three horticultural types: crisphead (Diamondback, Gabilan, Salute, Sidewinder, and Steamboat), romaine (Bondi), and red leaf (Fossey). Seeds of each cultivar were each sown in 140-well transplant trays filled with moistened potting soil (Sunshine Mix No. 1, Sun Gro Horticultural, Agawam, MA) on three dates 1 week apart, with each sowing date corresponding to a date of transplanting into the field. Immediately after sowing seed, transplant trays were covered with aluminum foil for 24 to $36 \mathrm{~h}$ to promote germination. Seedlings were maintained in a greenhouse for 5 weeks, wherein mean daily temperatures ranged from 24 to $28^{\circ} \mathrm{C}$ for the duration of seedling growth.

Seedlings that were prepared for the third planting date of 2016 had poor germination in the greenhouse. Consequently, an additional 140 seeds per cultivar were sown in trays at 6 days past the initial sowing date and maintained in a controlled environment growth chamber (Conviron model PGR15, Winnipeg, MB, Canada) for 4 weeks until transplanting. Growth chamber parameters were set for a 12-h photoperiod with day/night temperatures of $28 / 20^{\circ} \mathrm{C}$ and $60 \%$ relative humidity. A random selection of seedlings reared in greenhouse and growth chamber were used in the field experiment.

Field experiments. At the University of California, Davis, Plant Pathology research farm, seedlings were transplanted into field soil naturally infested with $F$. oxysporum f. sp. lactucae on three planting dates 1 week apart in August and September. The experiment was conducted in 2014, 2015, and 2016, with each experiment consisting of three planting dates and seven cultivars. Planting dates were August 21, August 28, and September 4 in 2014; August 20, August 27, and September 3 in 2015; and August 18, August 25, and September 1 in 2016. An area of approximately $330 \mathrm{~m}^{2}$ with nine 0.3 -m-wide raised planting beds was divided into six equally sized blocks. Each block included three planting dates for each of seven cultivars, for a total of 21 treatments replicated six times in a randomized complete block design. Within each block, treatments were randomly assigned to 3-m lengths of bed, with each treatment represented by 10 plants spaced approximately $30 \mathrm{~cm}$ apart. Randomization of treatments was unique to each block and year.

At 2, 3, 4, and 5 weeks after transplanting (WAT), plants were rated for severity of Fusarium wilt based on an ordinal scale of 1 to 4 (Scott et al. 2010a). Ratings were assigned as follows: $1=$ healthy, $2=$ mild stunting, $3=$ severe stunting and chlorosis/ necrosis, and $4=$ dead, with intermediate ratings of $1.5,2.5$, or 3.5 applied when appropriate. A stand count was taken 7 days after transplanting, and any dead plants were assumed to have died independently of the disease and were excluded from the dataset. Plants damaged by insect or mammalian herbivory or by wind whipping were also excluded.

The field used in this study was originally infested with $F$. oxysporum f. sp. lactucae using laboratory-reared inoculum as described by Scott et al. (2010b). Since that time, high inoculum densities of the pathogen have been maintained by regularly planting and incorporating susceptible lettuce. For the same purpose, lettuce was incorporated into soil at the conclusion of each field experiment conducted during the course of this study. In 2014 and 2015, plants received water by furrow irrigation, whereas in 2016 , water was applied through drip lines buried approximately $0.3 \mathrm{~m}$ deep. In each year, preemergent herbicide (Balan 2.5G, LebanonTurf, Lebanon, PA) was hydrated, sprayed on the soil surface, and incorporated prior to the first planting. Thereafter, weeds were removed by cultivation using a rototiller between beds and by hoeing within each bed. Aphids were suppressed by insecticidal soap (Safer Brand Insect Killing Soap Concentrate, Lititz, PA) and bifenthrin (Bifen 2 AG Gold, Agrian, Clovis, CA) as needed.

Ambient temperature in the field plot was recorded every 0.5 to $3.5 \mathrm{~h}$ for the duration of all experiments by a HOBO Pro Series data logger (models H08-032-08 or UX100-001, Onset Computer Corporation, Bourne, MA). Data loggers were placed inside a protective housing (M-RSA Assembled Solar Radiation Shield, Onset Computer Corporation) at approximately $1 \mathrm{~m}$ above the ground. Ambient temperature recorded by data loggers was used to estimate daily mean temperatures and daily maximum temperatures and to calculate growing degree days (GDD).
GDD were calculated based on a modified method for predicting corn maturity (Pruess 1983), which includes limits on daily maximum and daily minimum temperatures. Upper and lower thresholds for GDD were based on temperature limits for growth of $F$. oxysporum, as described by Haskell (1919). The maximum temperature limit for growth of $F$. oxysporum f. sp. lactucae was predicted to be $38^{\circ} \mathrm{C}$ and the minimum set at $5^{\circ} \mathrm{C}$. The equation for calculating daily GDD was as follows: GDD $=\left[\left(\mathrm{T}_{\max }+\mathrm{T}_{\min }\right) / 2\right]-\mathrm{T}_{\text {base }}$, where $\mathrm{T}_{\max }$ is the maximum daily temperature, $\mathrm{T}_{\min }$ is the minimum daily temperature, and $\mathrm{T}_{\text {base }}$ is equal to the minimum temperature threshold for growth of $F$. oxysporum, $5^{\circ} \mathrm{C}$. Conditions for the equation are that (i) if $\left(\mathrm{T}_{\max }+\mathrm{T}_{\min } / 2\right)$ is less than $\mathrm{T}_{\text {base }}$, then GDD is equal to 0 , and (ii) if $\mathrm{T}_{\max }$ exceeds $38^{\circ} \mathrm{C}$, then it is reset to $38^{\circ} \mathrm{C}$, the maximum temperature threshold for growth of $F$. oxysporum.

Soil dilution plating. Inoculum density of F. oxysporum f. sp. lactucae was estimated in the field plot using soil dilution plating. In October 2015 and August 2016, infested field soil was sampled from each block by removing a total of six 1-cm-diameter cores up to a depth of $22 \mathrm{~cm}$ from furrows with a soil auger. Within a block, soil cores were obtained from four corners and the midpoint of two center rows and combined into one composite sample. Soil samples were air dried at room temperature, 22 to $25^{\circ} \mathrm{C}$, for 2 to 3 weeks and then passed through a 4-mm sieve. Thereafter, soil samples were stored in a cold room at $4^{\circ} \mathrm{C}$ until assayed. Soil dilution plating was performed as described by Gordon et al. (1989). Soil dilutions were spread over the surface of Komada's selective medium (Komada 1975) in 100-mm-diameter Petri dishes and incubated under continuous fluorescent light at room temperature for 10 to 14 days. Colonies of $F$. oxysporum f. sp. lactucae on Komada's selective medium were visually differentiated from nonpathogenic Fusarium spp. based on colony morphology, as described by Scott et al. (2010a). Mean inoculum density ( \pm standard deviation) of $F$. oxysporum f. sp. lactucae across all six blocks was $334 \pm 56$ and $174 \pm 91$ CFU/g in soil samples collected in October 2015 and August 2016, respectively.

Development of Fusarium wilt in lettuce exposed to warm temperatures at different stages of growth. Lettuce seedlings. Crisphead cultivars of intermediate susceptibility, Steamboat and Sidewinder, were sown in transplant trays filled with moistened potting soil. Seeds were soaked in water for 24 to $36 \mathrm{~h}$ prior to sowing. Seeds were sown in each of the 180 cells per tray and placed in a growth chamber with a 12-h photoperiod and day/night temperatures of $23 / 18^{\circ} \mathrm{C}$. Immediately after sowing, transplant trays were covered with aluminum foil for a duration of 12 to $36 \mathrm{~h}$ to promote germination. For the first and second experiments, transplant trays were transferred to a greenhouse within $24 \mathrm{~h}$ of seedling emergence, where they were maintained for 30 to 32 days after sowing. Mean daily temperatures in the greenhouse ranged from 16 to $22^{\circ} \mathrm{C}$ for the duration of seedling growth. For the third experiment, seedlings were maintained in the growth chamber for 35 days after sowing. Trays were not moved to the greenhouse because of an infestation of Western flower thrips. For all experiments, multiple seeds were sown per cell, and after emergence seedlings were thinned as needed to leave one seedling per cell.

Preparation of infested potting soil. Sand infested with $F$. oxysporum $\mathrm{f}$. sp. lactucae was prepared as a source of inoculum for infesting batches of sterilized potting soil. Two batches of infested sand were prepared for this experiment. Sand (Lapis Lustre no. 60, Cemex USA, Houston, TX) was twice autoclaved for $60 \mathrm{~min}$ at $123^{\circ} \mathrm{C}$. A known pathogenic isolate of $F$. oxysporum $\mathrm{f}$. sp. lactucae (GL 1515) was grown on potato dextrose agar in 100-mm-diameter Petri dishes and incubated at room temperature for 2 to 3 weeks. Cultures were placed in a blender (Waring Blender Commercial 700 Model 31BL46) and macerated in 100 to $200 \mathrm{ml}$ of sterile deionized water. Approximately $600 \mathrm{ml}$ of resulting slurry was added to 2.5 liters of sterilized sand and thoroughly mixed by hand. Infested sand inoculum was air dried at room temperature and mixed once or twice daily for up to 2 weeks until completely dry, passed through a $500-\mu \mathrm{m}$ sieve, and stored in a cold room at $4^{\circ} \mathrm{C}$ until used. 
Infested soil was prepared by mixing potting soil (autoclaved three times at $123^{\circ} \mathrm{C}$ for $60 \mathrm{~min}$ ) with infested sand inoculum, at a 1:10 weight/weight mix of sand to potting soil. After thorough mixing, samples of infested soil were assayed for $F$. oxysporum f. sp. lactucae, using dilution plating as described above. In the first and second experiments, inoculum densities of $F$. oxysporum f. sp. lactucae were estimated to be $5.52 \times 10^{5}$ and $5.80 \times 10^{5} \mathrm{CFU} / \mathrm{g}$ for batches planted to Steamboat, respectively, and $7.03 \times 10^{5}$ and $8.42 \times 10^{5} \mathrm{CFU} / \mathrm{g}$ for batches planted to Sidewinder, respectively. The third experiment consisted of a single batch planted to each cultivar and was estimated to have an inoculum density of $5.83 \times 10^{5} \mathrm{CFU} / \mathrm{g}$.

Growth chamber experiments. Five-week-old seedlings of Steamboat and Sidewinder were transplanted into infested soil and maintained in a growth chamber with a 12-h photoperiod under cool conditions (day/night temperatures of $23 / 18^{\circ} \mathrm{C}$ ). A subset of plants was transferred to a warm growth chamber $\left(33 / 23^{\circ} \mathrm{C}\right)$ for 1 week at either 2,3, or 4 WAT. A subset of plants was maintained under cool conditions as an experimental control. This experiment was conducted three times. The first and second experiments each consisted of 20 plants per treatment group per cultivar, whereas the third experiment consisted of 10 plants per treatment group per cultivar. Each plant constituted an experimental replicate. Seedlings were transplanted to $10-\mathrm{cm}$ square plastic pots filled with infested potting soil (one plant per pot), and pots were placed on plastic trays. Plants were irrigated by adding water to trays. At 3 and 4 WAT, predatory mites on wheat bran were sprinkled on lettuce as a biological control for Western flower thrips.

At 2, 3, 4, 5, and 6 WAT into infested soil, ratings for severity of above-ground (foliar) symptoms of Fusarium wilt were recorded on an ordinal scale of 1 to 4 , as described above. At 6 WAT, the aboveground portion of each plant was harvested, placed into a paper bag, and oven dried at temperatures that ranged from 30 to $50^{\circ} \mathrm{C}$. After oven drying for 2 weeks, dry weight was recorded for each plant. Following collection of above-ground tissue, taproots were rated for symptom severity based on an ordinal rating scale of 1 to 5 , with $1=$ no discoloration, $2=$ mild discoloration and/or discoloration localized to cortex, $3=$ substantial discoloration throughout stele and cortex, $4=$ extensive necrosis and severe discoloration of stele and cortex, and $5=$ dead taproot.

Disease severity in soil with low inoculum density. Two crisphead cultivars of intermediate susceptibility to Fusarium wilt, Diamondback and Steamboat, were either direct seeded (October planting) or transplanted (April and August plantings) into field soil infested with $F$. oxysporum f. sp. lactucae. To prepare seedlings for planting dates in April and August, seeds were sown in cells of transplant trays filled with moistened potting soil. Immediately after

Table 1. Severity of Fusarium wilt of lettuce planted on different dates

\begin{tabular}{|c|c|c|c|c|c|c|}
\hline Cultivar & Type $^{u}$ & Susceptibility $^{\mathbf{v}}$ & Year ${ }^{w}$ & Date $^{x}$ & Mean $\pm \mathrm{SE}^{\mathbf{y}}$ & RE with $95 \% \mathrm{CI}^{\mathrm{z}}$ \\
\hline Bondi & Rom & High & 2014 & First & $4.0 \pm 0.0$ & $0.53 \pm 0.02 \mathrm{a}$ \\
\hline Bondi & Rom & High & 2014 & Second & $3.9 \pm 0.0$ & $0.45 \pm 0.03 \mathrm{~b}$ \\
\hline Bondi & Rom & High & 2014 & Third & $4.0 \pm 0.0$ & $0.52 \pm 0.02 \mathrm{a}$ \\
\hline Bondi & Rom & High & 2015 & First & $3.8 \pm 0.0$ & $0.57 \pm 0.05 \mathrm{a}$ \\
\hline Bondi & Rom & High & 2015 & Second & $3.6 \pm 0.1$ & $0.43 \pm 0.05 b$ \\
\hline Bondi & Rom & High & 2015 & Third & $3.6 \pm 0.1$ & $0.49 \pm 0.05 \mathrm{ab}$ \\
\hline Bondi & Rom & High & 2016 & First & $3.2 \pm 0.1$ & $0.52 \pm 0.06 \mathrm{a}$ \\
\hline Bondi & Rom & High & 2016 & Second & $3.1 \pm 0.1$ & $0.50 \pm 0.06 \mathrm{a}$ \\
\hline Bondi & Rom & High & 2016 & Third & $3.2 \pm 0.1$ & $0.48 \pm 0.06 \mathrm{a}$ \\
\hline Gabilan & Head & High & 2014 & First & $4.0 \pm 0.0$ & $0.58 \pm 0.03 \mathrm{a}$ \\
\hline Gabilan & Head & High & 2014 & Second & $3.6 \pm 0.1$ & $0.43 \pm 0.05 b$ \\
\hline Gabilan & Head & High & 2014 & Third & $3.7 \pm 0.1$ & $0.49 \pm 0.05 b$ \\
\hline Gabilan & Head & High & 2015 & First & $3.5 \pm 0.1$ & $0.51 \pm 0.05 \mathrm{ab}$ \\
\hline Gabilan & Head & High & 2015 & Second & $3.6 \pm 0.1$ & $0.58 \pm 0.05 \mathrm{a}$ \\
\hline Gabilan & Head & High & 2015 & Third & $3.1 \pm 0.1$ & $0.41 \pm 0.06 b$ \\
\hline Gabilan & Head & High & 2016 & First & $3.2 \pm 0.2$ & $0.53 \pm 0.07 \mathrm{ab}$ \\
\hline Gabilan & Head & High & 2016 & Second & $3.3 \pm 0.1$ & $0.55 \pm 0.06 \mathrm{a}$ \\
\hline Gabilan & Head & High & 2016 & Third & $3.0 \pm 0.1$ & $0.42 \pm 0.05 \mathrm{~b}$ \\
\hline Salute & Head & High & 2014 & First & $4.0 \pm 0.0$ & $0.62 \pm 0.03 \mathrm{a}$ \\
\hline Salute & Head & High & 2014 & Second & $3.8 \pm 0.1$ & $0.49 \pm 0.05 b$ \\
\hline Salute & Head & High & 2014 & Third & $3.6 \pm 0.1$ & $0.39 \pm 0.05 b$ \\
\hline Salute & Head & High & 2015 & First & $3.6 \pm 0.1$ & $0.60 \pm 0.05 \mathrm{a}$ \\
\hline Salute & Head & High & 2015 & Second & $3.3 \pm 0.1$ & $0.45 \pm 0.06 \mathrm{~b}$ \\
\hline Salute & Head & High & 2015 & Third & $3.2 \pm 0.1$ & $0.45 \pm 0.06 b$ \\
\hline Salute & Head & High & 2016 & First & $2.4 \pm 0.1$ & $0.37 \pm 0.05 b$ \\
\hline Salute & Head & High & 2016 & Second & $3.1 \pm 0.1$ & $0.59 \pm 0.06 \mathrm{a}$ \\
\hline Salute & Head & High & 2016 & Third & $3.0 \pm 0.1$ & $0.54 \pm 0.06 \mathrm{a}$ \\
\hline \multirow[t]{2}{*}{ Diamondback } & Head & Int & 2014 & First & $3.4 \pm 0.1$ & $0.71 \pm 0.05 \mathrm{a}$ \\
\hline & & & & & & (Continued on next page) \\
\hline
\end{tabular}

u Cultivars of lettuce were one of three types: crisphead (Head), romaine (Rom), or leaf.

${ }^{v}$ Level of susceptibility of cultivars to Fusarium wilt: high, intermediate (Int), or low.

${ }^{w}$ Experiment was conducted in years 2014, 2015, and 2016.

${ }^{x}$ Planting dates were August 21 (first), August 28 (second), and September 4 (third) in 2014; August 20 (first), August 27 (second), and September 3 (third) in 2015; and August 18 (first), August 25 (second), and September 1 (third) in 2016.

y Mean and standard error of the mean (SE) for ratings of above-ground disease severity on a 1 to 4 scale $(1=$ healthy and $4=$ dead $)$ at 5 weeks after planting into infested field soil.

${ }^{\mathrm{z}}$ Estimates of nonparametric relative effects (RE) of planting date by cultivar within each year and their 95\% confidence interval (95\% CI) weighted by sample size. Values not followed by a common letter indicate a significant difference at $P<0.05$ based on Tukey-type contrasts. 
sowing seed, transplant trays were covered with aluminum foil for 24 to $36 \mathrm{~h}$. Seedlings were maintained in a greenhouse for 5 weeks before transplanting into infested field soil. Mean daily temperatures in the greenhouse ranged from 23 to $25^{\circ} \mathrm{C}$ for seedlings used in the April planting and from 24 to $28^{\circ} \mathrm{C}$ for seedlings used in the August 2016 and 2017 plantings.

Infestations were established by incorporating residue of plants infected by F. oxysporum f. sp. lactucae into soil on the plant pathology research farm. This was done initially for a residue decomposition experiment, during the course of which soil was irrigated and tilled periodically over a period of approximately 3 years. In October of 2016, infested soil was dispersed into adjacent noninfested soil with a rototiller, thereby establishing an inoculum density gradient from lower to higher, from north to south ends, respectively, within an area of $113 \mathrm{~m}^{2}(26.2 \mathrm{~m} \times 4.3 \mathrm{~m})$. Between experiments, soil within the plot was always tilled from north to south to maintain the gradient.

The infested area was divided into six equally sized blocks on a north-south axis such that each block corresponded to a section of the inoculum gradient. Each block consisted of six raised planting beds of $4.3 \mathrm{~m}$ length by $0.3 \mathrm{~m}$ width formed parallel to the inoculum density gradient. Within a block, each of the two cultivars was assigned to three adjacent rows (subblocks) per block; assignment of cultivar to subblock was alternated from block to block. Each of the rows within a subblock constituted a replication. Crop residue was incorporated at the conclusion of each experiment in order to sustain pathogen populations in soil. For planting dates in April and August, 10 seedlings were transplanted into each bed, with a spacing of approximately $25 \mathrm{~cm}$. Seedlings that died within 3 days of transplanting were replaced with a new seedling from a transplant tray. For the planting date in October, pelleted seeds of Diamondback and raw seeds of Steamboat were directly sown at a high density into planting beds. Seedlings that emerged after direct sowing were thinned to 20 - to $25-\mathrm{cm}$ spacing.

Ratings for severity of foliar symptoms of Fusarium wilt were recorded for plantings in October 2015, April 2016, August 2016, and August 2017 once per week after planting, with final ratings recorded at $15,8,6$, and 7 weeks after planting, respectively. Final ratings for above-ground and below-ground symptoms were recorded when plants reached maturity, with lettuce maturing more slowly in cooler planting windows. Above-ground symptoms of Fusarium wilt were recorded based on an ordinal rating scale of 1 to 4 , as described above. Below-ground symptoms were visualized by splitting taproots laterally to expose vascular tissue. Discoloration in taproots was rated on an ordinal rating scale of 1 to 5 , as described above. Lettuce plants that died within 1 week of transplanting were excluded from the dataset.

Table 1. (Continued from previous page)

\begin{tabular}{|c|c|c|c|c|c|c|}
\hline Cultivar & Type $^{u}$ & Susceptibility $^{v}$ & Yearw & Date $^{x}$ & Mean $\pm \mathrm{SE}^{\mathrm{y}}$ & RE with $95 \% \mathrm{CI}^{2}$ \\
\hline Diamondback & Head & Int & 2014 & Second & $2.2 \pm 0.1$ & $0.38 \pm 0.05 b$ \\
\hline Diamondback & Head & Int & 2014 & Third & $2.3 \pm 0.1$ & $0.41 \pm 0.05 b$ \\
\hline Diamondback & Head & Int & 2015 & First & $2.0 \pm 0.1$ & $0.56 \pm 0.06 \mathrm{a}$ \\
\hline Diamondback & Head & Int & 2015 & Second & $1.7 \pm 0.1$ & $0.45 \pm 0.06 \mathrm{a}$ \\
\hline Diamondback & Head & Int & 2015 & Third & $1.7 \pm 0.1$ & $0.49 \pm 0.06 \mathrm{a}$ \\
\hline Diamondback & Head & Int & 2016 & First & $2.2 \pm 0.1$ & $0.53 \pm 0.06 \mathrm{ab}$ \\
\hline Diamondback & Head & Int & 2016 & Second & $2.2 \pm 0.1$ & $0.55 \pm 0.06 \mathrm{a}$ \\
\hline Diamondback & Head & Int & 2016 & Third & $1.9 \pm 0.1$ & $0.43 \pm 0.06 b$ \\
\hline Sidewinder & Head & Int & 2014 & First & $3.2 \pm 0.1$ & $0.62 \pm 0.05 \mathrm{a}$ \\
\hline Sidewinder & Head & Int & 2014 & Second & $2.9 \pm 0.2$ & $0.54 \pm 0.06 \mathrm{a}$ \\
\hline Sidewinder & Head & Int & 2014 & Third & $2.2 \pm 0.1$ & $0.36 \pm 0.05 b$ \\
\hline Sidewinder & Head & Int & 2015 & First & $2.4 \pm 0.1$ & $0.60 \pm 0.06 \mathrm{a}$ \\
\hline Sidewinder & Head & Int & 2015 & Second & $1.8 \pm 0.1$ & $0.43 \pm 0.06 b$ \\
\hline Sidewinder & Head & Int & 2015 & Third & $1.9 \pm 0.1$ & $0.47 \pm 0.06 b$ \\
\hline Sidewinder & Head & Int & 2016 & First & $1.9 \pm 0.1$ & $0.49 \pm 0.06 \mathrm{ab}$ \\
\hline Sidewinder & Head & Int & 2016 & Second & $2.1 \pm 0.1$ & $0.57 \pm 0.06 \mathrm{a}$ \\
\hline Sidewinder & Head & Int & 2016 & Third & $1.8 \pm 0.1$ & $0.44 \pm 0.06 b$ \\
\hline Steamboat & Head & Int & 2014 & First & $3.6 \pm 0.1$ & $0.71 \pm 0.05 \mathrm{a}$ \\
\hline Steamboat & Head & Int & 2014 & Second & $2.7 \pm 0.1$ & $0.42 \pm 0.05 b$ \\
\hline Steamboat & Head & Int & 2014 & Third & $2.5 \pm 0.1$ & $0.38 \pm 0.05 b$ \\
\hline Steamboat & Head & Int & 2015 & First & $3.0 \pm 0.1$ & $0.62 \pm 0.06 \mathrm{a}$ \\
\hline Steamboat & Head & Int & 2015 & Second & $2.4 \pm 0.1$ & $0.45 \pm 0.06 b$ \\
\hline Steamboat & Head & Int & 2015 & Third & $2.3 \pm 0.1$ & $0.43 \pm 0.05 b$ \\
\hline Steamboat & Head & Int & 2016 & First & $2.0 \pm 0.1$ & $0.43 \pm 0.06 b$ \\
\hline Steamboat & Head & Int & 2016 & Second & $2.6 \pm 0.1$ & $0.60 \pm 0.06 \mathrm{a}$ \\
\hline Steamboat & Head & Int & 2016 & Third & $2.1 \pm 0.1$ & $0.46 \pm 0.05 b$ \\
\hline Fossey & Leaf & Low & 2014 & First & $1.4 \pm 0.1$ & $0.47 \pm 0.05 \mathrm{a}$ \\
\hline Fossey & Leaf & Low & 2014 & Second & $1.8 \pm 0.2$ & $0.58 \pm 0.06 b$ \\
\hline Fossey & Leaf & Low & 2014 & Third & $1.3 \pm 0.1$ & $0.45 \pm 0.05 \mathrm{a}$ \\
\hline Fossey & Leaf & Low & 2015 & First & $1.5 \pm 0.1$ & $0.56 \pm 0.05 a$ \\
\hline Fossey & Leaf & Low & 2015 & Second & $1.2 \pm 0.1$ & $0.43 \pm 0.05 b$ \\
\hline Fossey & Leaf & Low & 2015 & Third & $1.3 \pm 0.0$ & $0.52 \pm 0.05 a b$ \\
\hline Fossey & Leaf & Low & 2016 & First & $1.2 \pm 0.0$ & $0.48 \pm 0.05 a$ \\
\hline Fossey & Leaf & Low & 2016 & Second & $1.4 \pm 0.1$ & $0.53 \pm 0.05 \mathrm{a}$ \\
\hline Fossey & Leaf & Low & 2016 & Third & $1.2 \pm 0.1$ & $0.49 \pm 0.05 \mathrm{a}$ \\
\hline
\end{tabular}


Planting beds were hand watered in the first week after planting but were otherwise irrigated with a drip line buried up to $10 \mathrm{~cm}$ deep. Preemergent herbicide (Balan 2.5G, LebanonTurf) was applied prior to each experiment, and weeds were removed regularly by hoeing. Ground squirrels and gophers transgressed a fence enclosing experimental plantings and severely damaged all plants in the August 2017 planting. Plants were allowed 5 weeks for recovery before being rated for symptoms of Fusarium wilt. With the exception of lettuce planted in August 2017, plants that were severely damaged by herbivory were excluded from the dataset. Ambient temperature at the field plot was recorded every $2 \mathrm{~h}$ by a HOBO Pro Series data logger (model UX100-001) positioned about $1 \mathrm{~m}$ above-ground inside protective housing (Onset M-RSA Assembled Solar Radiation Shield, Onset Computer Corp). For October 2015, April 2016, and August 2016 and 2017 plantings, daily means ranged from 2 to $23^{\circ} \mathrm{C}$, from 14 to $27^{\circ} \mathrm{C}$, from 16 to $26^{\circ} \mathrm{C}$, and from 16 to $31^{\circ} \mathrm{C}$, respectively.

Soil dilution plating. On February 2, 2016, August 25, 2016, and October 26, 2017, infested soil was sampled up to 15 to $20 \mathrm{~cm}$ deep from each block using a soil auger. Six 1-cm-diameter cores were removed from furrows in the corners of each block and the center of two middle furrows. Soil cores were combined into a single composite sample for each block. Soil samples were air dried for 2 to 3 weeks, passed through a 4-mm sieve, and stored at $4{ }^{\circ} \mathrm{C}$ until assayed. Inoculum densities of $F$. oxysporum $\mathrm{f}$. sp. lactucae ranged from below 10 $\mathrm{CFU} / \mathrm{g}$ at the north end of the plot to $125 \mathrm{CFU} / \mathrm{g}$ at the south end. Detection thresholds for assays were $21 \mathrm{CFU} / \mathrm{g}$ for samples collected in February 2016 and October 2017 and 10 CFU/g for samples collected in August 2016.

Data analysis. Statistical analyses were performed using $\mathrm{R}$ version 3.4.0 (R Foundation for Statistical Computing, Vienna, Austria) and RStudio version 1.1.383 (RStudio, Boston, MA). The R software packages rankFD (Brunner et al. 2017; Konietschke et al. 2016) and nparcomp (Konietschke et al. 2015) were employed for rank-based analysis and nonparametric multiple contrasts of disease severity data. The rank-based procedures of rankFD and nparcomp are suitable for ordinal and heteroscedastic data (Brunner et al. 2017; Konietschke et al. 2012). Using the rankFD function of rankFD, ANOVA-type $P$ tests and estimates of nonparametric weighted relative effects and their 95\% confidence intervals were derived from the midranks of observations, as described by Shah and Madden (2004). Relative effects indicated the probability that a randomly selected observation under a treatment was greater or less than the mean rank distribution, with a value of 0.5 indicating no significant effect of treatment. Likewise, a value greater than 0.5 indicated that observations under a treatment tend to be larger than those from the mean rank distribution, whereas values lower than 0.5 represented a tendency for observations to be smaller. Significance of treatment effects for ordinal data were evaluated based on ANOVA-type statistics and overlap (or not) of 95\% confidence intervals for relative effects. Using the mctp function of nparcomp, Tukey contrast matrices based on global rankings were used for computation of adjusted $P$ values for pairwise comparisons. Statistics for nonparametric Tukey-type contrast tests were computed using a multivariate $t$ distribution with a Satterthwaite approximation of the degree of freedom. Data manipulation and analysis were assisted with R packages dplyr (Wickham et al. 2017), car (Fox et al. 2017), and agricolae (De Mendiburu 2017).

\section{Results}

Planting dates 1 to 2 weeks apart. Severity of Fusarium wilt varied by planting date and cultivar (Table 1). The largest differential in disease severity was observed for Diamondback in 2014, for which mean ratings were $3.4 \pm 0.1$ in the first planting and $2.2 \pm 0.1$ in the second planting (Table 1). Highly susceptible cultivars suffered severe damage from Fusarium wilt regardless of planting date, whereas mean disease severity for the resistant cultivar Fossey was always low (Table 1).

Based on symptoms that developed during planting date experiments, cultivars were grouped by susceptibility in three categories (low, intermediate, or high) for analysis using ANOVA-type statistics (ATS). Fossey was placed in the low category; Diamondback, Sidewinder, and Steamboat were in the intermediate category; and Bondi, Gabilan, and Salute were in the high-susceptibility category. For the low-susceptibility group, which consisted of a single cultivar, a two-way ATS indicated that the interaction of year $\times$ planting date was significant $(P=0.001)$, so the main effect of planting date on disease severity in Fossey was analyzed by year. The effect of planting date was a significant source of variation in $2014(P=$ $0.013)$ and $2015(P=0.016)$ but not in $2016(P=0.494)$.

In the high-susceptibility group, the three-way interaction of cultivar $\times$ year $\times$ planting date was significant $(P<0.001)$. Accordingly, severity data were analyzed separately by year. These analyses showed the interaction of cultivar $\times$ planting date to be significant in all three years $(P<0.001$ in all cases). Consequently, the effect of planting date on disease severity was analyzed with a one-way ATS by cultivar within each year. Planting date was a significant source of variation for Bondi in $2014(P=0.003)$ and $2015(P=$ $0.009)$ but not in $2016(P=0.780)$; the effect of planting date was significant in all three years for Gabilan and Salute, with $P \leq$ 0.041 and $P \leq 0.002$, respectively.

In the intermediate-susceptibility group, the cultivar $x$ year $x$ planting date interaction was significant $(P=0.020)$. Consequently, two-way analyses were conducted separately for disease severity data from each year. The interaction of cultivar $\times$ planting date was significant in $2014(P=0.001)$ but not in $2015(P=0.863)$ or $2016(P=0.238)$. In 2015 and 2016, the effects of cultivar $(P \leq$ $0.009)$ and planting date $(P<0.001)$ were significant. In 2014, planting date was a significant source of variation for disease severity in all cultivars of intermediate susceptibility $(P<0.001)$.

For first, second, and third planting dates, mean daily high/low temperatures from 1 to 35 days after transplanting (DAT) differed by no more than $1.6^{\circ} \mathrm{C}$ (Table 2), yet this modest differential was associated with differences in disease severity in moderately susceptible cultivars. To gain better resolution on an effect of temperature, ambient temperatures from several time periods were compared across planting dates, based on the mean of daily mean temperatures, mean of daily maximum temperatures, and cumulative GDD over several time periods.

In 2014 and 2015, both the mean of daily mean and mean of daily maximum temperatures were markedly higher 20 to 25 days after the first planting than during the same interval after the second and third plantings (Table 2). In those years, the cultivars Sidewinder, Steamboat, and Salute developed significantly more severe symptoms of Fusarium wilt in the first planting, compared with the second and third plantings (Table 1). Cumulative GDD was also highest at 20 to 25 days after the first planting, compared with the second and third plantings. In 2016, mean of daily mean and mean of daily maximum temperatures and cumulative GDD at 20 to 25 DAT were higher during the second planting than during the same interval after the first and third plantings (Table 2). During this year, the cultivars Diamondback, Sidewinder, Steamboat, Salute, and Gabilan had significantly more severe symptoms in the second planting, compared with the first and/or third plantings (Table 1). There was not a consistent relationship between high temperatures at 20 to 25 DAT and disease severity in all highly susceptible or resistant cultivars.

Spearman's rank correlation coefficient was used to test the relationship between temperatures at 20 to 25 DAT and mean ratings for severity of Fusarium wilt for cultivars of intermediate susceptibility. Mean severity ratings for Diamondback, Sidewinder, and Steamboat were pooled across years and planting dates to test for a correlation with corresponding measurements per year and per planting date for cumulative GDD, mean of daily maximum temperatures, and mean of daily mean temperatures. There was a moderate positive correlation of mean severity rating with cumulative GDD $(\rho=0.381$, $P=0.049)$ and with mean of daily mean temperatures $(\rho=0.374, P=$ 0.055 ) but a weaker positive correlation of mean severity rating with mean of daily maximum temperatures, which was not significant $(\rho=$ $0.261, P=0.187)$. Spearman's rank correlation coefficient indicated no significant correlation of mean severity ratings with cumulative GDD, mean of daily mean temperatures, or mean of daily maximum 
temperatures for any of the 6-day intervals before or after 20 to 25 DAT (analyses not shown).

Development of Fusarium wilt in lettuce exposed to warm temperatures at different stages of growth. Above-ground symptoms were present in the first and second experiments, albeit at a low severity (range of mean ratings $=1.2$ to 1.7 ) but were nearly absent (range of mean ratings $=1.0$ to 1.1 ) in the third experiment. Therefore, analysis was limited to data from the first two experiments. A three-way ATS showed that interactions of experiment $\times$ cultivar $\times$ treatment $(P=0.698)$, experiment $\times$ treatment $(P=0.648)$, experiment $\times$ cultivar $(P=0.914)$, and cultivar $\times$ treatment $(P=0.692)$ were all not significant. The effect of experiment was significant $(P=$ 0.023 ), reflecting severity ratings that were greater by an average of 0.16 per treatment in the second compared with the first experiment. Severity ratings were slightly higher for Sidewinder than Steamboat, but the effect of cultivar was not significant $(P=0.113)$.

Because no interactions were significant, above-ground ratings were pooled across cultivars in the first two experiments for subsequent analyses. Lettuce exposed to warm temperatures at either 2 or 3 WAT developed significantly $(P<0.05)$ more severe symptoms (mean rating $=1.6 \pm 0.1)$ than the control group (mean rating $=1.3 \pm 0.1)$.
Severity of Fusarium wilt in lettuce exposed to high temperature at 4 WAT (mean rating $=1.3 \pm 0.1$ ) was significantly lower $(P<0.05)$ than in the other high-temperature treatments and not significantly different from the control group. Plants tended to develop more severe symptoms of Fusarium wilt after exposure to warm temperatures at 2 and 3 WAT, as indicated by relative effects of $0.64 \pm 0.07$ and $0.62 \pm 0.06$ in Sidewinder, respectively, and $0.53 \pm 0.07$ and $0.59 \pm$ 0.07 in Steamboat, respectively (Table 3).

Some degree of discoloration in the taproot was evident in all three experiments. A three-way ATS for data on severity of taproot symptoms showed the experiment $\times$ cultivar interaction to be significant $(P<0.001)$, but the experiment $\times$ cultivar $\times$ treatment interaction $(P=0.085)$, experiment $\times$ treatment interaction $(P=0.123)$, and cultivar $\times$ treatment interaction $(P=0.186)$ were all not significant.

Owing to a significant experiment $\times$ cultivar interaction, a twoway ATS for data on severity of taproot symptoms was applied by cultivar. For both Sidewinder and Steamboat, the main effects of experiment and treatment were significant $(P \leq 0.005)$, with no significant interaction for experiment $\times$ treatment $(P=0.074$ and $P=$ 0.053 , respectively). Below-ground severity ratings were therefore pooled across experiments per cultivar to improve statistical power

Table 2. Temperatures and growing degree days (GDD) during three planting dates in 2014, 2015, and 2016

\begin{tabular}{|c|c|c|c|c|c|c|}
\hline \multirow[b]{2}{*}{ Year ${ }^{\mathbf{u}}$} & \multirow[b]{2}{*}{ Planting date ${ }^{v}$} & \multicolumn{2}{|c|}{ Seasonal means ${ }^{w}$} & \multicolumn{2}{|c|}{ 20- to 25-day means } & \multirow[b]{2}{*}{ 20- to 25-day cumulative GDD } \\
\hline & & High $\left({ }^{\circ} \mathrm{C}\right)$ & Low $\left({ }^{\circ} \mathrm{C}\right)$ & $\operatorname{Mean}\left({ }^{\circ} C\right)^{x}$ & Maximum $\left({ }^{\circ} \mathbf{C}\right)^{y}$ & \\
\hline 2014 & First & 32.9 & 14.3 & 25 & 37 & 121 \\
\hline 2014 & Second & 32.0 & 13.5 & 22 & 31 & 108 \\
\hline 2014 & Third & 31.9 & 13.1 & 19 & 25 & 85 \\
\hline 2015 & First & 33.2 & 14.2 & 25 & 36 & 123 \\
\hline 2015 & Second & 32.1 & 14.2 & 22 & 32 & 101 \\
\hline 2015 & Third & 31.6 & 13.9 & 23 & 34 & 114 \\
\hline 2016 & First & 32.1 & 12.3 & 21 & 32 & 105 \\
\hline 2016 & Second & 32.3 & 12.1 & 22 & 34 & 107 \\
\hline 2016 & Third & 30.7 & 11.4 & 21 & 32 & 100 \\
\hline
\end{tabular}

u Year the experiment was conducted.

v Planting dates were August 21 (first), August 28 (second), and September 4 (third) in 2014; August 20 (first), August 27 (second), and September 3 (third) in 2015; and August 18 (first), August 25 (second), and September 1 (third) in 2016.

${ }^{w}$ Mean daily high and low temperatures for the duration of the experimental planting (35 days).

x Mean of daily mean temperatures between 20 and 25 days after transplanting (DAT).

y Mean of daily maximum temperatures between 20 and 25 DAT.

${ }^{\mathrm{z}}$ Cumulative GDD from 20 to $25 \mathrm{DAT}$; GDD calculated based on lower threshold of $5^{\circ} \mathrm{C}$ and upper threshold of $38^{\circ} \mathrm{C}: \mathrm{GDD}=\left(\mathrm{T}_{\max }+\mathrm{T}_{\min } / 2\right)-5 ; \mathrm{T}_{\max }=38$ if greater than $38^{\circ} \mathrm{C} ; \mathrm{GDD}=0$ if $\left(\mathrm{T}_{\max }+\mathrm{T}_{\min } / 2\right)$ is less than $5^{\circ} \mathrm{C}$.

Table 3. Effect of 1-week exposure to high temperature on severity of Fusarium wilt and dry weight of two lettuce cultivars

\begin{tabular}{|c|c|c|c|c|c|c|}
\hline \multirow[b]{2}{*}{ Cultivar } & \multirow[b]{2}{*}{ Treatment $^{\mathrm{u}}$} & \multicolumn{2}{|c|}{ Above-ground disease severity } & \multicolumn{2}{|c|}{ Below-ground disease severity } & \multirow[b]{2}{*}{ Dry weight $(\text { mean } \pm S E)^{z}$} \\
\hline & & Mean $\pm \mathrm{SE}^{\mathbf{v}}$ & $\mathrm{RE} \pm 95 \% \mathrm{CI}^{\mathrm{w}}$ & Mean $\pm \mathrm{SE}^{\mathrm{x}}$ & $\mathrm{RE} \pm 95 \% \mathrm{CI}^{\mathrm{y}}$ & \\
\hline Sidewinder & Control & $1.3 \pm 0.1$ & $0.38 \pm 0.06 \mathrm{~b}$ & $1.5 \pm 0.1$ & $0.34 \pm 0.06 \mathrm{~b}$ & $1.62 \pm 0.09 \mathrm{c}$ \\
\hline Sidewinder & Week 2 & $1.7 \pm 0.1$ & $0.64 \pm 0.07 \mathrm{a}$ & $2.2 \pm 0.1$ & $0.64 \pm 0.05 \mathrm{a}$ & $2.00 \pm 0.09 \mathrm{~b}$ \\
\hline Sidewinder & Week 3 & $1.6 \pm 0.1$ & $0.62 \pm 0.06 \mathrm{a}$ & $2.0 \pm 0.1$ & $0.55 \pm 0.05 \mathrm{ab}$ & $1.92 \pm 0.09 \mathrm{bc}$ \\
\hline Sidewinder & Week 4 & $1.2 \pm 0.1$ & $0.37 \pm 0.06 b$ & $1.8 \pm 0.1$ & $0.46 \pm 0.06 \mathrm{~b}$ & $2.45 \pm 0.12 \mathrm{a}$ \\
\hline Steamboat & Control & $1.2 \pm 0.1$ & $0.42 \pm 0.06 \mathrm{~b}$ & $1.8 \pm 0.2$ & $0.32 \pm 0.07 \mathrm{c}$ & $1.16 \pm 0.07 \mathrm{~b}$ \\
\hline Steamboat & Week 2 & $1.6 \pm 0.1$ & $0.53 \pm 0.07 \mathrm{ab}$ & $3.0 \pm 0.1$ & $0.62 \pm 0.06 \mathrm{a}$ & $1.58 \pm 0.13 \mathrm{a}$ \\
\hline Steamboat & Week 3 & $1.6 \pm 0.1$ & $0.59 \pm 0.07 \mathrm{a}$ & $2.9 \pm 0.1$ & $0.59 \pm 0.06 \mathrm{ab}$ & $1.47 \pm 0.10 \mathrm{ab}$ \\
\hline Steamboat & Week 4 & $1.3 \pm 0.1$ & $0.46 \pm 0.06 a b$ & $2.4 \pm 0.1$ & $0.48 \pm 0.06 \mathrm{~b}$ & $1.61 \pm 0.09 \mathrm{a}$ \\
\hline
\end{tabular}

${ }^{\mathrm{u}}$ Lettuce cultivars Sidewinder and Steamboat were maintained in a growth chamber under cool conditions $\left(23 / 18^{\circ} \mathrm{C}\right)$, and a subset of plants was transferred to a warm growth chamber $\left(33 / 23^{\circ} \mathrm{C}\right)$ for 1 week at either 2,3 , or 4 weeks after transplanting (WAT). Plants in the control group were not exposed to warm temperatures.

${ }^{v}$ Mean and standard error of the mean (SE) for ratings of above-ground disease severity on a 1 to 4 scale $(1=$ healthy and $4=$ dead) at 6 WAT. Ratings were pooled across the first and second experiments $(n=40)$.

${ }^{w}$ Estimates of nonparametric relative effects (RE) of treatment on above-ground disease severity by cultivar and their $95 \%$ confidence interval (95\% CI). Values not followed by a common letter indicate a significant difference at $P<0.05$ based on Tukey-type contrasts.

${ }^{x}$ Mean and SE for ratings of below-ground disease severity on a 1 to 5 scale $(1=$ no discoloration and $5=$ dead taproot $)$ at 6 WAT. Ratings were pooled across three experiments $(n=50)$.

${ }^{y}$ Estimates of nonparametric RE of treatment on below-ground disease severity by cultivar and their $95 \%$ CI. Values not followed by a common letter indicate a significant difference at $P<0.05$ based on Tukey-type contrasts.

${ }^{z}$ Mean shoot dry weight (grams) \pm SE of lettuce 6 weeks after planting. Dry weights were pooled across the first and second experiments $(n=40)$. Values not followed by a common letter indicate a significant difference at $P<0.05$ based on Tukey's honestly significant difference test. 
for detecting effects of treatment. A one-way ATS on pooled data indicated a significant effect of treatment on below-ground disease severity at $P<0.001$ for both cultivars.

For both Sidewinder and Steamboat, the most severe taproot symptoms occurred in plants exposed to warm temperatures at 2 WAT (Table 3). In both cases, severity ratings for this treatment were significantly higher than all other treatments, except for the warmtemperature treatment at 3 WAT (Table 3). Spearman's rank correlation coefficient showed a moderate, positive correlation of above-ground severity ratings and below-ground severity ratings for cultivars Sidewinder $(\rho=0.367 ; P<0.001)$ and Steamboat $(\rho=0.458$; $P<0.001)$.

\section{A Above-ground symptoms, Diamondback}

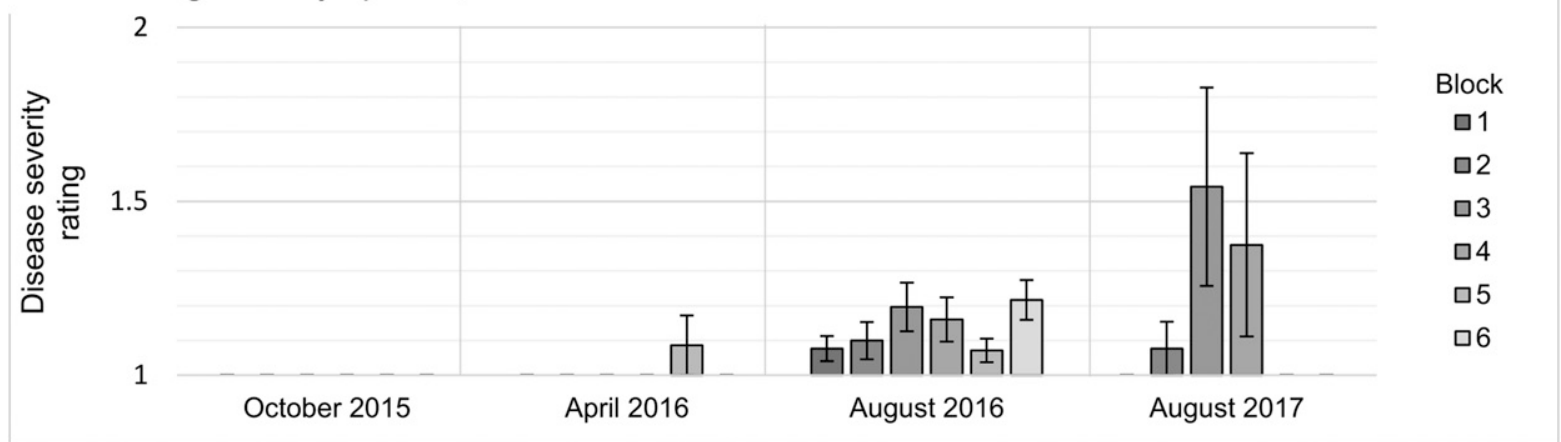

\section{B Above-ground symptoms, Steamboat}

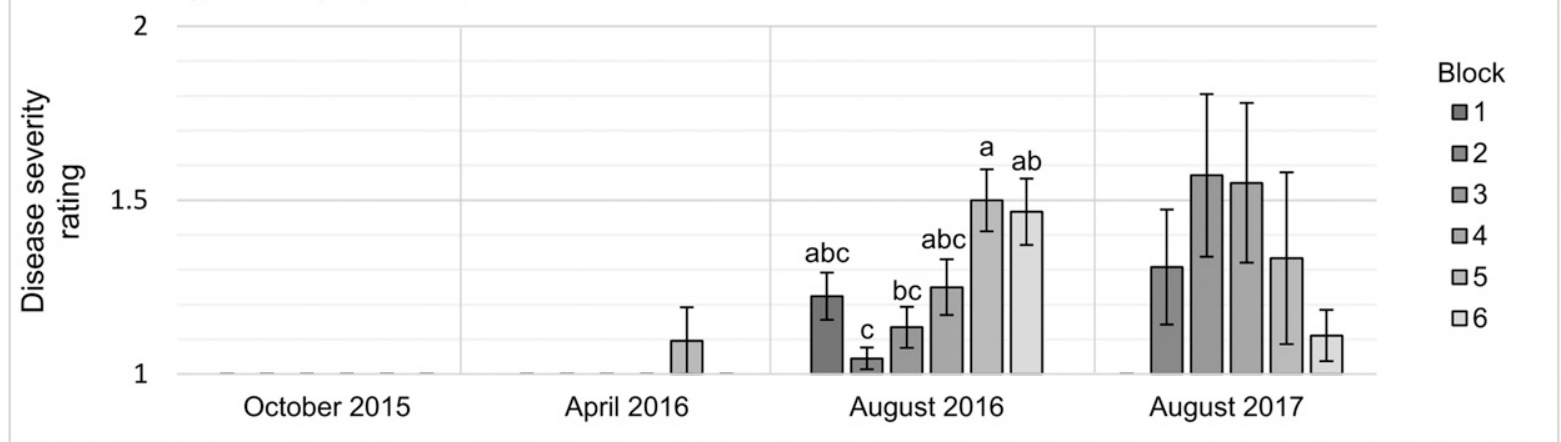

\section{Below-ground symptoms, Diamondback}

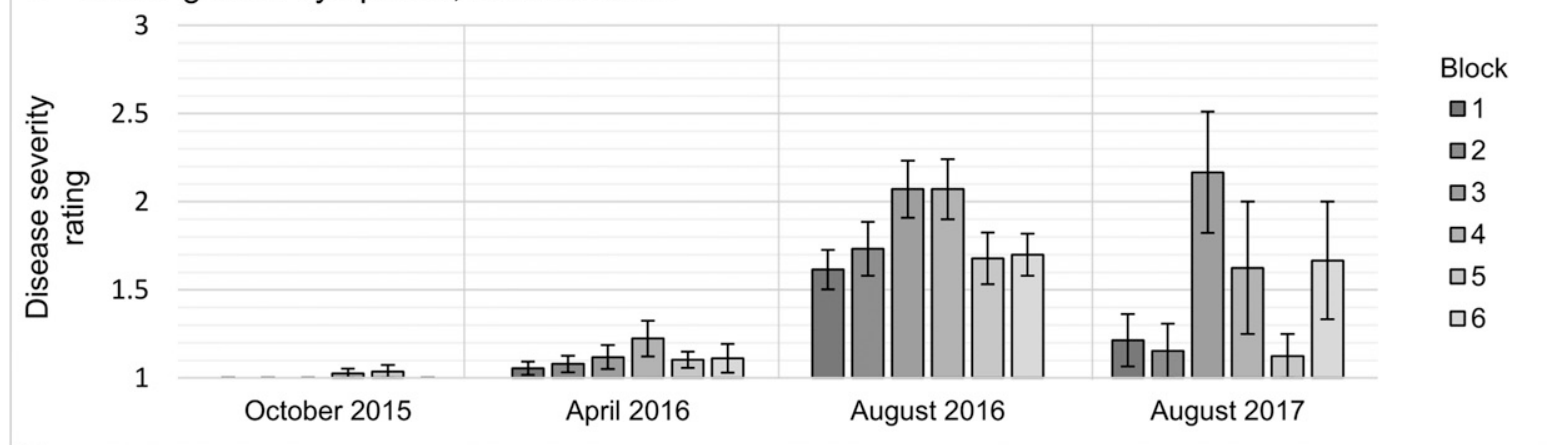

\section{Below-ground symptoms, Steamboat}

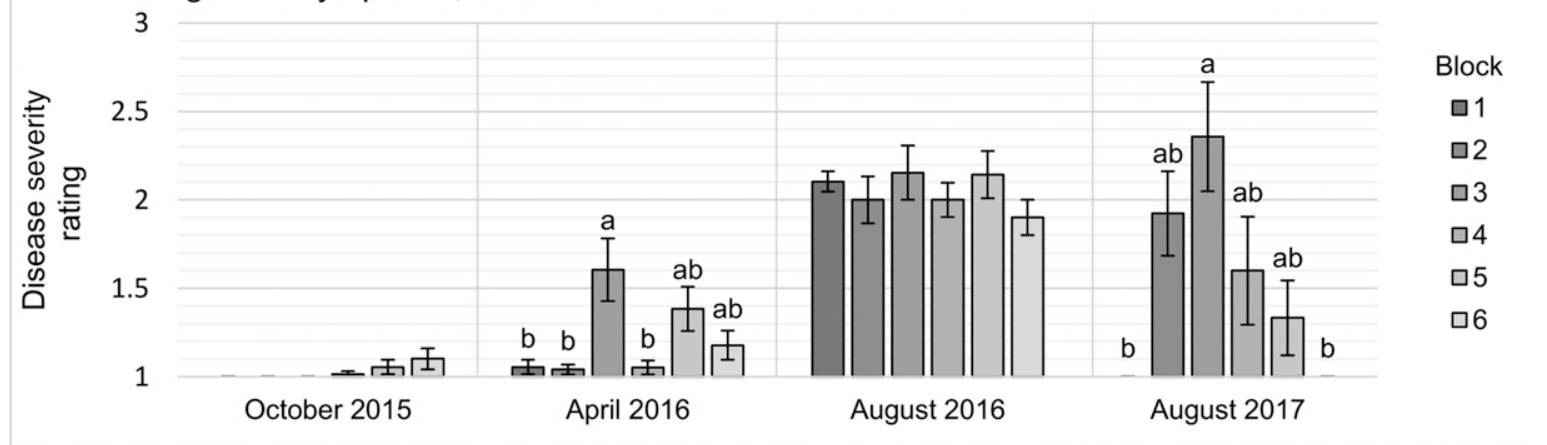

Fig. 1. Severity of Fusarium wilt in moderately susceptible lettuce for plantings in October 2015, April 2016, August 2016, and August 2017 in a plot with low inoculum levels of Fusarium oxysporum $\mathrm{f}$. sp. lactucae, with inoculum density roughly increasing from blocks 1 to 6 , rated for above-ground severity on a 1 to 4 scale $(1=$ healthy and $4=$ dead) in $\mathbf{A}$, Diamondback and B, Steamboat, and below-ground severity on a 1 to 5 scale $(1=$ no discoloration and $5=$ dead taproot) in C, Diamondback and D, Steamboat. Bars represent mean of ratings, and error bars correspond to $2 \times$ the standard error of the mean. Within a planting date, bars for mean ratings that do not share a letter are significantly different at $P<0.05$ based on Tukey-type contrasts. Letters were excluded when there was no significant effect of inoculum density (= block) on disease severity within a planting date. 
Based on dry weight of lettuce in the first and second experiments, a three-way ANOVA indicated that interactions of experiment $\times$ cultivar $\times$ treatment $(P=0.465)$, experiment $\times$ treatment $(P=0.220)$, experiment $\times$ cultivar $(P=0.313)$, and cultivar $\times$ treatment $(P=0.063)$ were not significant. Main effects of experiment $(P<0.001)$, cultivar $(P<0.001)$, and treatment $(P<0.001)$ were significant sources of variation for dry weight. Lettuce exposed to higher temperatures at 2 and 4 WAT had significantly greater dry weight than in the control group (Table 3 ). Dry weight of lettuce in the warm-temperature treatment at 3 WAT was not significantly different from the control group. Differences in dry weight among warm-temperature treatments were not significant for Steamboat, whereas Sidewinder exposed to high temperatures at 4 WAT had significantly greater dry weight than in all other treatments. Based on Spearman's rank correlation coefficient, above-ground severity ratings were negatively correlated with dry weight $(\rho=-0.420, P<0.001)$. Dry weight was also negatively correlated with below-ground severity ratings $(\rho=$ $-0.270, P<0.001$ ), although the correlation was weaker than for above-ground severity. More severe symptoms of Fusarium wilt were associated with a lower dry weight in plants.

Planting date in field with a low inoculum density of $F$. oxysporum f. sp. lactucae. Averaged over samples taken in February 2016, August 2016, and October 2017, mean inoculum densities for blocks 1 to 6 were $0,0,38,17,35$, and $49 \mathrm{CFU} / \mathrm{g}$, respectively. The highest inoculum density was $125 \mathrm{CFU} / \mathrm{g}$, in samples taken in October 2017 from block 6. Accordingly, blocks in this experiment correspond to differences in inoculum density and did not constitute replications. The effects of inoculum density, cultivar, and the interaction of inoculum density and cultivar on disease development in moderately susceptible lettuce were assessed based on above-ground and belowground severity of Fusarium wilt.

Above-ground symptoms of Fusarium wilt were evident in all plantings except October 2015, for which all plants retained a healthy appearance for the duration of the experiment. In each of the other plantings, Fusarium wilt was generally more severe in blocks with higher inoculum densities of $F$. oxysporum $\mathrm{f}$. sp. lactucae, with more pronounced differences in disease severity discerned among blocks in warmer planting windows (Fig. 1A and B). In the April 2016 planting, the effects of cultivar $(P=0.939)$, inoculum density $(P=0.164)$, and the cultivar $\times$ inoculum density interaction $(P=0.939)$ were all not significant. With data pooled across cultivars, the effect of inoculum density on disease severity was not significant $(P=0.159)$.

Above-ground symptoms of Fusarium wilt were mild even in warmer planting dates of August 2016 and 2017, with the highest mean severity ratings of $1.5 \pm 0.3$ for Diamondback and $1.6 \pm 0.2$ for Steamboat. The effects of cultivar and inoculum density on above-ground symptoms were significant both in the August 2016 planting $(P=0.003$ and $P=0.001$, respectively) and in the August 2017 planting $(P=0.018$ and $P=0.031$, respectively). The cultivar $\times$ inoculum density interaction was significant in the August 2016 planting $(P=0.002)$ but not in the August 2017 planting $(P=$ $0.816)$. To account for a significant interaction of cultivar $\times$ inoculum density, above-ground ratings of the August 2016 planting were analyzed by cultivar. Inoculum density was a significant source of variation for above-ground severity ratings for the cultivar Steamboat $(P<0.001)$ but not for the cultivar Diamondback $(P=0.353)$. For the August 2017 planting, a one-way ATS, with data pooled across cultivars, showed the effect of inoculum density to be significant $(P=0.030)$.

Below-ground symptoms of Fusarium wilt were mostly absent in the October 2015 planting, with mild taproot discoloration in a few plants in blocks 4, 5, and 6 (Fig. 1C and 1D). Effects of cultivar $(P=0.435)$ and inoculum density $(P=0.188)$ were both not significant. More plants had discolored taproots in the April 2016 planting, and a two-way ATS indicated the effects of cultivar and inoculum density were significant $(P=0.044$ and $P=0.003$, respectively), but the cultivar $\times$ inoculum density interaction was also significant $(P=0.004)$. Analyzing data for cultivars separately, the effect of inoculum density on disease severity was significant for Steamboat $(P<$ $0.001)$ but not Diamondback $(P=0.811)$.
In August 2016, below-ground severity ratings for Steamboat ranged from $1.9 \pm 0.1$ to $2.2 \pm 0.2$ and for Diamondback from $1.6 \pm 0.1$ to $2.1 \pm 0.2$. Although differences were not large, the effect of cultivar on disease severity was significant $(P<0.001)$, whereas the effects of inoculum density and the cultivar $x$ inoculum density interaction were not $(P \geq 0.260)$. In the August 2017 planting there was a wider range of severity ratings between blocks, and the effect of inoculum density was significant $(P=0.012)$, but the effect of cultivar was not $(P=0.853)$. The cultivar $\times$ inoculum density interaction was significant $(P=0.033)$. Analyzed separately by cultivar, the effect of inoculum density on disease severity was significant for Steamboat $(P<0.001)$ but not for Diamondback $(P=0.192)$.

\section{Discussion}

Lettuce is grown throughout most of the year in California and in both coastal and inland areas. Seasonal and regional differences correspond to a wide range of temperatures under which a lettuce crop can be grown. These differences can be exploited to reduce the risk of damage from Fusarium wilt. In an experiment conducted at the same location as the present study, disease severity in the susceptible cultivar Early Queen was shown to be significantly lower 25 days after planting when planted in July, than when planted 1 month earlier, when daily mean high temperatures were as much as $6^{\circ} \mathrm{C}$ greater than during the July planting (Scott et al. 2010b). A question that motivated the present study was whether or not shorter planting date differentials, and presumably more moderate differences in temperature, would also influence severity of Fusarium wilt.

Our finding shows that a 1-week difference in planting date had a significant impact on severity of Fusarium wilt, even for the resistant cultivar Fossey. Although the severity rating for Fossey never exceeded 1.8, the effect of planting date was significant in both 2014 and 2015. For the three highly susceptible cultivars, the effect of planting date was significant in all years, except for Bondi in 2016, although the magnitude of differences was always small (Table 1). The most substantial effects were observed in moderately susceptible cultivars. In 2014, the differential in mean disease severity between planting dates ranged from 1.0 to 1.2 for Diamondback, Sidewinder, and Steamboat. Lesser differences were observed in 2015 and 2016 , ranging from 0.3 to 0.7 . Reductions in this range can be beneficial if disease severity is thereby reduced to 1.0 (no symptoms) or close thereto. In other words, whether or not an effect of planting date makes a meaningful contribution to disease management will be strongly influenced by other factors that affect disease severity, such as cultivar susceptibility and inoculum levels in soil.

The influence of temperature on severity of Fusarium wilt presumably reflects effects on both the host and the pathogen. Lettuce is a cool-season crop that grows optimally at temperatures below 23 to $25^{\circ} \mathrm{C}$ (Seginer et al. 1991; Turini et al. 2011), whereas the optimal temperature for growth of $F$. oxysporum $\mathrm{f}$. sp. lactucae is between 25 and $30^{\circ} \mathrm{C}$ (Scott et al. 2010a). Accordingly, temperatures above $25^{\circ} \mathrm{C}$ are expected to be more favorable to the pathogen than the host. Results from field experiments in the present study suggest that ambient temperature in the period 20 to 25 days after transplanting may have been the key determinant of an effect on disease severity, whereas growth chamber experiments point to the second and third week after transplanting as the intervals in which warm temperatures are most impactful. Heightened vulnerability to temperature at this stage may be owing to a greater transpirational surface area than in younger plants, enhancing the magnitude of stress to which the plant is subjected. High temperatures at later growth stages may have failed to enhance disease development because there was not sufficient time for an advantage to the pathogen to become apparent before the experiment was terminated. Our findings present a refined picture of temperature effects on disease, which can help to inform decisions concerning planting windows within which susceptible cultivars can be grown. Of course, future temperatures are never known with certainty, so decisions are guided by seasonal norms.

The incidence and severity of Fusarium wilt diseases will always be influenced by the level of inoculum to which plants are exposed. For example, Scott et al. (2010b) demonstrated an effect of inoculum 
levels on severity of Fusarium wilt in lettuce cultivars, based on rootdip assays and growth in infested potting mix. A correlation between inoculum levels and disease severity has also been described for Fusarium wilts of chickpea (Bhatti and Kraft 1992; Navas-Cortés et al. 2000), cotton (Hao et al. 2009), carnation (Ben-Yephet et al. 1994), and cyclamen (Elmer 2002). Our studies were undertaken to better understand the influence of soil inoculum density on Fusarium wilt of lettuce under field conditions. The results showed little or no impact of disease on cultivars of intermediate susceptibility, even in warmer planting windows, when grown in soil with low inoculum levels (<125 CFU per gram). Above-ground symptoms of Fusarium wilt were typically absent in cooler planting windows, with mean ratings of 1.0 in the October 2015 planting and not higher than 1.1 in the April 2016 planting. Although below-ground symptoms (extent of taproot discoloration) were positively correlated with above-ground symptoms, damage to the taproot was often observed in plants that were symptomless above-ground. Thus, although above-ground damage may be avoided when inoculum levels are low, pathogen growth in the taproot will allow for increases in the pathogen population in soil.

In summary, more effective management of Fusarium wilt can be achieved by judicious selection of cultivars based on the temperature regime to which plantings are likely to be subjected and by avoiding fields with high inoculum levels. Our findings suggest that levels below $125 \mathrm{CFU} / \mathrm{g}$ are unlikely to be damaging to cultivars of intermediate susceptibility. Of course, this threshold is not absolute and will vary with ambient temperatures and cultivar susceptibility. To take full advantage of the information that is now available, cultivar susceptibility ratings must be available to growers. Seed companies can provide this information based on root-dip assays, the results of which correlate well with field performance (Scott et al. 2010b). Knowledge of soil inoculum levels is also important, and although cultural assays can provide this information (Scott et al. 2010a), a more cost-effective procedure will be required before a routine test to quantify pathogen inoculum levels in soil is widely available.

\section{Acknowledgments}

The authors gratefully acknowledge technical assistance from Zion CongraveWilson, Coralie Donkers, Lauren Downing, Robert Farr, Aimee Hopkins, Samuel Johnson, Neville Mathews, Annie Montes, Melodie Navarro, Jaskaran Sahota, Michelle Stueven, Dean Watson, and Jenna Yoshisato.

\section{Literature Cited}

Ben-Yephet, Y., Reuven, M., and Genizi, A. 1994. Effects of inoculum depth and density on Fusarium wilt in carnations. Phytopathology 84:1393-1398.

Bhatti, M., and Kraft, J. 1992. Effects of inoculum density and temperature on root rot and wilt of chickpea. Plant Dis. 76:50-54.

Brunner, E., Konietschke, F., Pauly, M., and Puri, M. L. 2017. Rank-based procedures in factorial designs: Hypotheses about non-parametric treatment effects. J. R. Stat. Soc. B 79:1463-1485.

De Mendiburu, F. 2017. Agricolae: Statistical procedures for agricultural research. Version 1.2.8. R Project for Statistical Computing. https://cran.r-project.org

Elmer, W. H. 2002. Influence of inoculum density of Fusarium oxysporum f. sp. cyclaminis and sodium chloride on cyclamen and the development of Fusarium wilt. Plant Dis. 86:389-393.

Fox, J., Friendly, G. G., Graves, S., Heiberger, R., Monette, G., Nilsson, H., Ripley, B., Weisberg, S., Fox, M. J., and Suggests, M. 2017. The car package. Version 2.1.6. R Project for Statistical Computing. https://cran.rproject.org
Garibaldi, A., Gilardi, G., and Gullino, M. L. 2004a. Seed transmission of Fusarium oxysporum $\mathrm{f}$. sp. lactucae. Phytoparasitica 32:61-65.

Garibaldi, A., Gilardi, G., and Gullino, M. L. 2004b. Varietal resistance of lettuce to Fusarium oxysporum f. sp. lactucae. Crop Prot. 23:845-851.

Gordon, T. R., and Koike, S. T. 2015. Management of Fusarium wilt of lettuce. Crop Prot. 73:45-49.

Gordon, T. R., Okamoto, D., and Jacobson, D. J. 1989. Colonization of muskmelon and nonsusceptible crops by Fusarium oxysporum f. sp. melonis and other species of Fusarium. Phytopathology 79:1095-1100.

Hao, J. J., Yang, M. E., and Davis, R. M. 2009. Effect of soil inoculum density of Fusarium oxysporum f. sp. vasinfectum race 4 on disease development in cotton. Plant Dis. 93:1324-1328.

Haskell, R. J. 1919. Fusarium wilt of potato in the Hudson River Valley. Phytopathology 9:223-260.

Hubbard, J., and Gerik, J. 1993. New wilt disease of lettuce incited by Fusarium oxysporum f. sp. lactucum forma specialis nov. Plant Dis. 77:750-755.

Komada, H. 1975. Development of a selective medium for quantitative isolation of Fusarium oxysporum from natural soil. Rev. Plant Prot. Res. 8:114-124.

Konietschke, F., Friedrich, S., Brunner, E., and Pauly, M. 2016. RankFD: RankBased Tests for General Factorial Designs. Version 0.0.1. https://rdrr.io/cran/ rankFD/

Konietschke, F., Hothorn, L. A., and Brunner, E. 2012. Rank-based multiple test procedures and simultaneous confidence intervals. Electron. J. Stat. 6:738-759.

Konietschke, F., Placzek, M., Schaarschmidt, F., and Hothorn, L. A. 2015 nparcomp: An R software package for nonparametric multiple comparisons and simultaneous confidence intervals. Version 2.6. R Project for Statistical Computing. https://cran.r-project.org

Matheron, M., and Koike, S. 2003. First report of Fusarium wilt of lettuce caused by Fusarium oxysporum f. sp. lactucae in Arizona. Plant Dis. 87:1265.

Matheron, M. E., McCreight, J. D., and Tickes, B. R. 2005. Effect of planting date, cultivar, and stage of plant development on incidence of Fusarium wilt of lettuce in desert production fields. Plant Dis. 89:565-570.

Matheron, M. E., and Porchas, M. 2010. Evaluation of soil solarization and flooding as management tools for Fusarium wilt of lettuce. Plant Dis. 94: $1323-1328$

Matuo, T., and Motohashi, S. 1967. On Fusarium oxysporum f. sp. lactucae n. f. causing root rot of lettuce. (Translated.). Mycol. Soc. Jpn. 32:13-15.

Navas-Cortés, J. A., Alcalá-Jiménez, A. R., Hau, B., and Jiménez-Díaz, R. M. 2000. Influence of inoculum density of races 0 and 5 of Fusarium oxysporum f. sp. ciceris on development of Fusarium wilt in chickpea cultivars. Eur. J. Plant Pathol. 106:135-146.

Pruess, K. P. 1983. Day-degree methods for pest management. Environ. Entomol. 12:613-619.

Scott, J., Gordon, T., Kirkpatrick, S., Koike, S., Matheron, M., Ochoa, O., Truco, M., and Michelmore, R. 2012. Crop rotation and genetic resistance reduce risk of damage from Fusarium wilt in lettuce. Calif. Agric. 66:20-24.

Scott, J. C., Gordon, T. R., Shaw, D. V., and Koike, S. T. 2010a. Effect of temperature on severity of Fusarium wilt of lettuce caused by Fusarium oxysporum f. sp. lactucae. Plant Dis. 94:13-17.

Scott, J. C., Kirkpatrick, S. C., and Gordon, T. R. 2010b. Variation in susceptibility of lettuce cultivars to Fusarium wilt caused by Fusarium oxysporum f. sp. lactucae. Plant Pathol. 59:139-146.

Scott, J. C., McRoberts, D. N., and Gordon, T. R. 2014. Colonization of lettuce cultivars and rotation crops by Fusarium oxysporum f. sp. lactucae, the cause of Fusarium wilt of lettuce. Plant Pathol. 63:548-553.

Seginer, I., Shina, G., Albright, L. D., and Marsh, L. S. 1991. Optimal temperature setpoints for greenhouse lettuce. J. Agric. Eng. Res. 49:209-226.

Shah, D. A., and Madden, L. V. 2004. Nonparametric analysis of ordinal data in designed factorial experiments. Phytopathology 94:33-43.

Turini, T., Cahn, M., Cantwell, M., Jackson, L., Koike, S., Natwick, E., Smith, R., Subbarao, K., and Takele, E. 2011. Iceberg lettuce production in California. Vegetable Production Series. Publication 7215. University of California Agricultural and Natural Resources, Richmond, CA.

Wickham, H., Francois, R., Henry, L., and Müller, K. 2017. dplyr: A grammar of data manipulation. R package. Version 0.7.4. R Core Development Team, Vienna, Austria. 